\title{
Modul Inkuiri Berbasis Potensi dan Kearifan Lokal pada Materi Biologi: Sebuah Penelitian Pengembangan
}

\author{
Ummi Nur Afinni Dwi Jayanti ${ }^{1}$, Herawati Susilo ${ }^{1}$, Endang Suarsini ${ }^{1}$ \\ ${ }^{1}$ Pendidikan Biologi-Universitas Negeri Malang
}

\section{INFO ARTIKEL}

\section{Riwayat Artikel:}

Diterima: 23-07-2018

Disetujui: $17-09-2020$

Kata kunci:
inquiry module;
local culture;
local potential;
modul inkuiri;
kearifan lokal;
potensi lokal

Alamat Korespondensi:

Ummi Nur Afinni Dwi Jayanti

Pendidikan Biologi

Universitas Negeri Malang

Jalan Semarang 5 Malang

E-mail: ummifinni2310@gmail.com

\section{ABSTRAK}

\begin{abstract}
The purpose of this research is to know the validity and practicality of inquiry module based on the potential and local wisdom on the material of plant diversity, ecosystem, and environmental change for the students of grade X SMAN 1 Padang Cermin. The type of this research is development research and uses ADDIE development model of which was limited to Develop phase. The validity of the module was measured from the expert's validation score, while the practicality is known from the student's response. The results showed that the average validation score by media and teaching materials experts showed a percentage of $94.4 \%$ (very suitable for use), material experts of $82.6 \%$ (very suitable to use), field practitioners $92.8 \%$ (very suitable for use) and students responded $83.5 \%$ (very suitable to use). The conclusion of this research is that the generated inquiry module based on the potential and local wisdom is valid and practical so it can be implemented further to the students of grade X SMA 1 Padang Cermin.
\end{abstract}

\begin{abstract}
Abstrak: Tujuan penelitian ini yaitu untuk mengetahui kevalidan dan kepraktisan modul inkuiri berbasis potensi dan kearifan lokal pada materi keanekaragaman tumbuhan, ekosistem, dan perubahan lingkungan untuk siswa kelas X SMAN 1 Padang Cermin. Jenis penelitian ini adalah penelitian pengembangan dan menggunakan model pengembangan ADDIE yang dibatasi pada tahap Develop. Kevalidan modul diketahui dari skor validasi ahli, sedangkan kepraktisan diketahui dari respon siswa. Hasil penelitian menunjukkan bahwa rerata skor validasi oleh ahli media dan bahan ajar menunjukkan persentase sebesar 93,1\% (sangat layak digunakan), ahli materi sebesar $82,6 \%$ (sangat layak digunakan), praktisi lapangan sebesar 92,8\% (sangat layak digunakan) dan siswa memberikan respon sebesar $83,5 \%$ (respon positif). Kesimpulan dari penelitian ini yaitu dihasilkan modul inkuiri berbasis potensi dan kearifan lokal yang valid dan praktis sehingga dapat diimplementasikan lebih lanjut kepada siswa kelas X SMA 1 Padang Cermin.
\end{abstract}

Desentralisasi pengelolaan pendidikan yang tercantum dalam Undang-Undang Republik Indonesia Nomor 32 Tahun 2004 bertujuan untuk menciptakan dan mengembangkan sistem pendidikan nasional yang sesuai dengan kebutuhan dan kondisi daerah serta perkembangan di tingkat lokal, nasional, maupun global (Basari, 2014). Hal ini didukung oleh kurikulum yang pada semua jenjang dan jenis pendidikan di Indonesia dikembangkan dengan prinsip diversifikasi sesuai dengan satuan pendidikan, potensi daerah, dan siswa dengan memperhatikan keragaman potensi daerah dan lingkungan (Undang-undang Republik Indonesia Nomor 30 Tahun 2003, 2003). Selain itu, penerapan Kurikulum 2013 memberikan ruang bagi pendidik untuk mengembangkan kurikulum daerah berbasis keunggulan lokal melalui pengayaan materi dan alat ajar pendukung yang bermutu dan beragam (Kristiani, 2016).

Pendidikan berbasis keunggulan lokal bertujuan untuk mempersiapkan siswa yang memiliki wawasan lokal terkait kondisi alam, lingkungan sosial, lingkungan budaya daerahnya, serta memiliki sikap dan perilaku melestarikan dan mengembangkan sumber daya alam, kualitas sosial, dan kebudayaan untuk mendukung pembangunan tingkat daerah maupun nasional (Basari, 2014). Hal tersebut sesuai dengan teori belajar bermakna (Ausubel, Novak, \& Hanesian, 1978) terkait pembelajaran yang bersifat kontekstual dan penerimaan bahwa apa yang dipelajari siswa akan berguna di masa depan akan membuat pembelajaran menjadi semakin menarik. Salah satu potensi kontekstual yang berpeluang diangkat sebagai sumber belajar yang menarik di sekolah yaitu potensi dan kearifan lokal daerah. 
Taman Hutan Raya Wan Abdul Rachman (Tahura WAR) merupakan salah satu potensi lokal kabupaten di Lampung yang terletak di lintas Kota Bandar Lampung dan Kabupaten Pesawaran (UPTD Tahura WAR, 2008). Berdasarkan (Peraturan Pemerintah Republik Indonesia Nomor 108 tahun 2015, 2015), Tahura merupakan kawasan pelestarian alam untuk tujuan koleksi tumbuhan atau satwa alami atau bukan alami, spesies asli atau bukan asli yang dimanfaatkan bagi kepentingan penelitian ilmu pengetahuan, pendidikan, penunjang budidaya tumbuhan dan atau satwa, budaya, pariwisata, dan rekreasi. Tahura WAR memiliki ketinggian topografi bervariasi (landai, curam, dan sangat curam) serta dibentuk oleh daerah perbukitan dan pegunungan. Menurut data (UPTD Tahura WAR, 2008), kawasan Tahura WAR memiliki kawasan hutan primer, sekunder, dan hutan hasil reboisasi yang masing-masing kawasan tersebut memiliki flora dan fauna yang berbeda. Spesies flora yang terdapat di kawasan Tahura WAR antara lain beberapa jenis lumut, paku, lichenes, serta tanaman bertajuk tinggi dan rendah yang termasuk dalam kajian biologi. Selain itu, masyarakat di sekitar Tahura WAR mempunyai kearifan lokal dalam kegiatan budidaya tumbuhan secara turun temurun yang memiliki aspek pelestarian lingkungan (Desuciani, 2012). Potensi tersebut dapat diintegrasikan dalam mata pelajaran sebagai bentuk pemanfaatan potensi lokal (Marliana \& Hikmah, 2013) sebagai sumber belajar terutama untuk materi Biologi.

Hasil kajian analisis kesesuaian dengan Kompetensi Inti (KI) dan Kompetensi Dasar (KD) pada Kurikulum 2013 menunjukkan bahwa potensi dan kearifan lokal masyarakat di sekitar Tahura WAR dapat dijadikan sumber belajar untuk materi biologi kelas X mencakup topik Keanekaragaman Tumbuhan, Ekosistem, dan Perubahan Lingkungan. Potensi flora Tahura WAR (paku-pakuan, lumut, tanaman bertajuk tinggi dan rendah) serta pemanfaatan tumbuhan obat oleh masyarakat di sekitar Tahura WAR sesuai dengan KD 3.8 yaitu mengelompokkan tumbuhan ke dalam divisi berdasarkan ciri umum, serta mengaitkan peranannya dalam kehidupan (Peraturan Menteri Pendidikan dan Kebudayaan Nomor 24 Tahun 2016, 2016.) Tahura WAR merupakan ekosistem hutan hujan tropis yang di dalamnya terdapat interaksi antar makhluk hidup relevan dengan KD 3.10 pada KD Biologi Permendikbud No. 24 Tahun 2016 yaitu menganalisis komponen ekosistem dan interaksi antar komponen tersebut. Hasil penelitian terpublikasi berkaitan dengan Tahura WAR menunjukkan adanya perubahan kondisi lingkungan Tahura WAR dari waktu ke waktu yang dapat dijadikan bahasan materi pada KD 3.11(Permendikbud No. 24 Tahun 2016) yaitu menganalisis data perubahan lingkungan, penyebab, dan dampaknya bagi kehidupan sehingga siswa mendapatkan pembelajaran kontekstual yang bersumber dari lingkungan sekitarnya.

Sumber belajar kontekstual akan lebih bermakna jika diolah dan disusun menjadi bahan ajar (Prastowo, 2015) yang mencakup tujuh komponen (judul, petunjuk belajar, kompetensi dasar, materi pokok, informasi pendukung, latihan, tugas atau langkah kerja, dan penilaian). Bahan ajar yang memenuhi ketujuh komponen struktur bahan ajar tersebut adalah modul. Modul yang dikembangkan dalam penelitian ini yaitu modul inkuiri terbimbing berbasis potensi dan kearifan lokal Tahura WAR. Hal ini sesuai dengan reformasi standar kurikulum sains yang menganjurkan pembelajaran inkuiri dalam pembelajaran sains (Tytler, 2007). Model inkuiri terbimbing dipilih karena dapat melatih siswa untuk mengonstruk pengetahuan secara mandiri untuk mendapat konsep biologi yang dapat diterapkan dalam kehidupannya (Colburn, 2000; Fang et al., 2016) melalui proses inkuiri dengan pertanyaan-pertanyaan baru untuk diselidiki (Llewellyn, 2013). Crawford, (2007) \& Minner et al. (2010) melaporkan bahwa pembelajaran sains berbasis inkuiri mempunyai potensi untuk meningkatkan pemahaman konsep siswa dan keterlibatan dalam sains dan literasi ilmiah. Aktivitas inkuri terbimbing memberikan kesempatan bagi sistwa untuk berpikir layaknya seperti ilmuwan (Labouta et al., 2018). Selain itu, aktivitas inkuiri terbimbing memberikan kesempatan kepada siswa untuk memainkan peran yang aktif di dalam kelas dan memungkinkan guru menjadi fasilitator pengalaman belajar (Aditomo \& Klieme, 2020; Mullins, 2017). Dengan demikian, siswa lebih leluasa dalam mengeksplorasi materi pelajaran dan memfasilitasi perkembangan kemampuan kerjasama dalam proses pembelajaran (Fakayode et al., 2017; Mullins, 2017). Mundy \& Potgieter (2019) dan Song (2016) melaporkan bahwa penerapan model inkuiri terbimbing memberikan hasil positif pada perilaku dan hasil belajar siswa. Selain itu, tingkat kepercayaan diri siswa meningkat (De Gale \& Boisselle, 2015) dan terdapat peningkatan kemampuan pemecahan masalah (Fakayode et al., 2017; Hein, 2012) dan berpikir kritis (Fakayode et al., 2017). Stender et al., (2018) melaporkan bahwa siswa mendapat peningkatan keterampilan menalar melalui aktivitas inkuri terbimbing. Inkuiri terbimbing juga memberikan manfaat dalam peningkatan pemahaman pengetahuan konten sains dan keterampilan sains (Bunterm et al., 2014; Koksal \& Berberoglu, 2014). Model inkuiri terbimbing mendorong motivasi siswa sehingga mengarahkan pada perilaku positif dan minat dalam karir di bidang sains (Bevins \& Price, 2016).

Keterampilan abad 21 mencakup keterampilan berpikir kritis, problem solving, literasi, kemampuan kolaborasi dan kesadaran global (Binkley, 2012; Greenstein, 2012) dapat dikembangkan melalui penerapan modul inkuiri terbimbing. Modul yang dikembangkan perlu melalui tahapan validasi ahli dan uji coba agar dapat diterapkan dalam proses pembelajaran. Penelitian ini bertujuan untuk mengetahui kevalidan dan kepraktisan modul inkuiri berbasis potensi dan kearifan lokal kawasan Tahura Wan Abdul Rahman (Tahura WAR). 


\section{METODE}

Penelitian ini merupakan penelitian pengembangan yang mengadaptasi model penelitian \& pengembangan ADDIE (Branch, 2009) yang terdiri atas lima tahapan yaitu Analyze, Design, Develop, Implement, dan Evaluate. Penelitian ini dibatasi hingga tahap Develop. Tahap Analyze dilakukan dengan cara menyebarkan angket analisis kebutuhan kepada guru dan siswa, identifikasi profil kemampuan siswa terhadap penguasaan keterampilan abad 21, serta melaksanakan studi lapangan pada potensi lokal yang diambil sebagai sumber belajar modul yang dikembangkan. Tahap Design dilakukan dengan cara membuat rancangan modul. Tahap Develop dilakukan dengan cara mengembangkan modul sesuai rancangan, memvalidasi modul kepada validator, dan melakukan uji coba pendahuluan kepada kelompok kecil siswa untuk uji keterbacaan modul dan memperoleh respon siswa terhadap modul.

Validator dalam penelitian ini yaitu dosen Teknologi Pendidikan UM dan dosen FMIPA UM dengan kualifikasi pendidikan S3 dan masa kerja \pm 10 tahun sebagai ahli media dan bahan ajar serta ahli materi. Sementara itu, guru Biologi SMAN 1 Padang Cermin dengan kualifikasi pendidikan S1 dan masa kerja \pm 10 tahun bertindak sebagai validatorpraktisi lapangan. Subjek dalam penelitian ini yaitu 10 orang siswa SMAN 1 Padang Cermin. Instrumen pengumpulan data yang digunakan yaitu lembar validasi modul dan angket respons siswa terhadap modul. Jenis data dalam penelitian ini antara lain data kuantitatif berupa skor validasi yang diberikan oleh validator dan skor angket respon siswa serta data kualitatif berupa komentar dan saran yang diberikan oleh validator (pada lembar validasi) dan siswa (pada angket respon siswa). Teknik analisis data hasil validasi modul menggunakan analisis persentase skor dengan rumus seperti pada Gambar 1a dan 1b. Kriteria kevalidan modul berdasarkan analisis persentase dapat dilihat pada tabel 1.

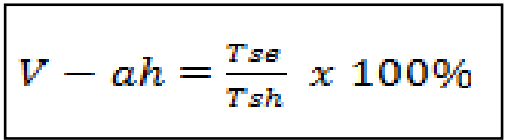

(a)

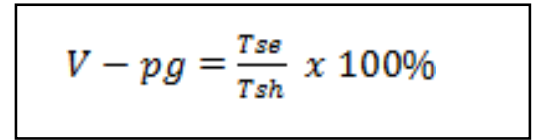

(b)

Gambar 1. (a) Rumus analisis data validasi modul oleh ahli (b) rumus analisis data validasi modul oleh praktisi lapangan

\section{Keterangan:}

$V$-ah: validitas ahli

Tse: pencapaian total skor empirik validator

$T s h$ : skor maksimal yang diharapkan
$V$-pg: praktisi lapangan

Tse: pencapaian total skor empirik validator

$T s h$ : skor maksimal yang diharapkan

Tabel 1. Kriteria Kevalidan Modul Berdasarkan Persentase Skor

\begin{tabular}{cl}
\hline Persentase Skor & \multicolumn{1}{c}{ Kriteria Penilaian } \\
\hline $81-100 \%$ & Sangat valid; dapat digunakan tanpa perbaikan \\
$61-80 \%$ & Valid; dapat digunakan namun perlu perbaikan kecil \\
$41-60 \%$ & Cukup valid; disarankan tidak digunakan \\
$21-40 \%$ & Kurang valid; tidak dapat digunakan \\
$0-20 \%$ & Tidak valid; tidak dapat digunakan \\
\hline
\end{tabular}

(Sumber: Akbar, 2015:41)

Teknik analisis data hasil angket keterbacaan dan respon siswa menggunakan analisis persentase dengan rumus sebagai berikut. Kriteria keterbacaan siswa terhadap modul dapat dilihat pada tabel 2, sedangkan kriteria respons siswa terhadap modul dapat dilihat pada tabel 3 .

Tabel 2. Kriteria Keterbacaan Modul Berdasarkan Persentase Skor

\begin{tabular}{cl}
\hline Persentase Skor & Kriteria Penilaian \\
\hline $81-100 \%$ & Sangat praktis \\
$61-80 \%$ & Praktis \\
$41-60 \%$ & Cukup Praktis \\
$21-40 \%$ & Kurang Praktis \\
$0-20 \%$ & Tidak Praktis \\
\hline
\end{tabular}

(Sumber: Akbar, 2015) 
Tabel 3. Kriteria Respons Siswa

\begin{tabular}{ll}
\hline Respons Siswa & Kriteria Penilaian \\
\hline RS $\geq 85 \%$ & Sangat Positif \\
$70 \% \leq \mathrm{RS}<85 \%$ & Positif \\
$50 \% \leq \mathrm{RS}<70 \%$ & Kurang Positif \\
$\mathrm{RS}<50 \%$ & Tidak Positif \\
\hline
\end{tabular}

(Sumber: Diadaptasi dari Khabibah (dalam Yamasari, 2010)

HASIL

Produk yang dihasilkan pada penelitian \& pengembangan ini yaitu modul inkuiri berbasis potensi dan kearifan lokal kawasan Taman Hutan Raya Wan Abdul Rachman untuk materi biologi siswa kelas X SMA. Berdasarkan analisis kebutuhan, permasalahan yang muncul, antara lain (1) kegiatan pembelajaran masih bersifat satu arah yaitu guru memberikan materi pelajaran melalui metode ceramah dan siswa mencatat informasi dari guru; (2) model pembelajaran yang digunakan guru belum mampu mengembangkan keterampilan abad 21 siswa sehingga penguasaan keterampilan abad 21 siswa masih dalam kategori sedang; (3) siswa kurang terlibat dalam penemuan konsep dan sumber belajar; (4) ketersediaan sumber dan bahan ajar yang belum memadai. Lembar Kerja Siswa yang digunakan siswa merupakan LKS yang dibuat oleh penerbit tertentu dan memiliki beberapa kekurangan yaitu tidak adanya variasi warna serta kegiatan dan materi pelajaran yang belum sesuai dengan Kompetensi Dasar Kurikulum 2013. Selain itu, sumber belajar yang digunakan guru masih belum kontekstual yang menggunakan sumber belajar dari lingkungan sekitar siswa. Hal ini terlihat dari hasil analisis kebutuhan yang menunjukkan bahwa guru dan siswa belum mengetahui konsep potensi dan kearifan lokal daeah Pesawaran serta guru belum pernah mengintegrasikan potensi lokal Tahura WAR dalam pembelajaran Biologi.

Kajian lebih lanjut terkait potensi Tahura WAR melalui kegiatan observasi lapangan dan kajian jurnal terpublikasi menunjukkan bahwa Tahura WAR mempunyai potensi keanekaragaman flora dan fauna, kondisi alam, dan konflik sosial masyarakat disekitarnya yang dapat diintegrasikan dalam materi pembelajaran biologi. Hasil analisis tersebut menjadi dasar penentuan materi dancover modul yang dikembangkan. Materi modul mencakup materi Keanekaragaman Tumbuhan, Ekosistem, dan Perubahan Lingkungan. Cover modul dapat dilihat pada gambar 2. Modul ini divalidasi oleh ahli media dan bahan ajar, ahli materi, serta praktisi lapangan, kemudian dilakukan uji coba pendahuluan terhadap modul kepada 10 orang siswa.
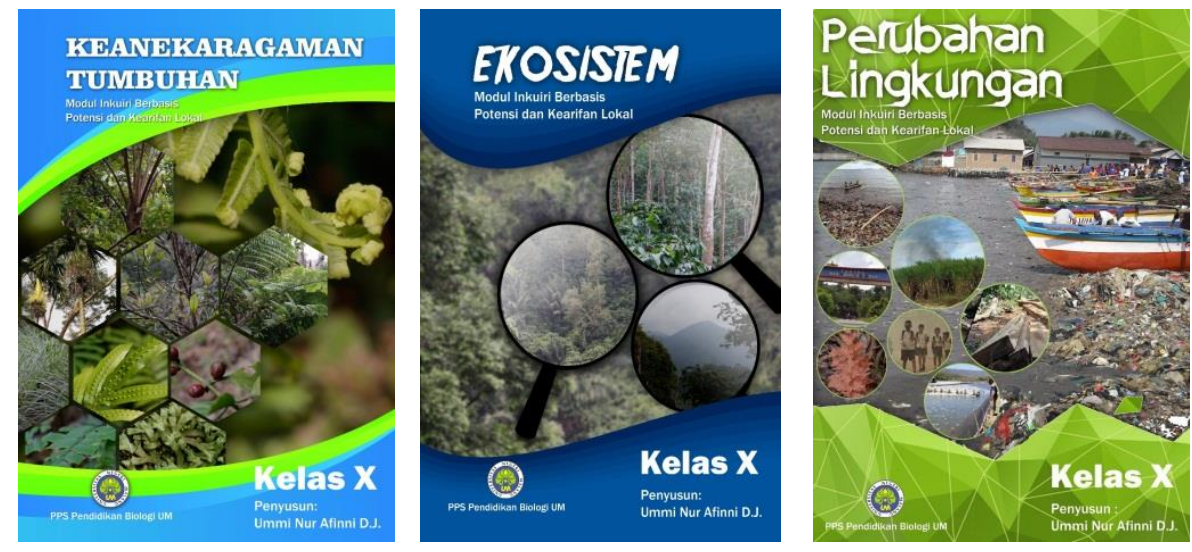

\section{Gambar 2. Tampilan Cover Modul Inkuiri Berbasis Potensi dan Kearifan Lokal}

Karakteristik modul inkuiri berbasis potensi dan kearifan lokal pada materi Keanekaragaman Tumbuhan, Ekosistem, dan Perubahan lingkungan adalah sebagai berikut:

a. Memiliki sub bagian antara lain: Deskripsi Singkat; Kompetensi Inti dan Kompetensi Dasar; Kerangka Isi; Indikator dan Tujuan Pembelajaran; Petunjuk Penggunaan Modul; Kegiatan Pembelajaran; Refleksi Kegiatan; Latihan Mandiri; Pengayaan (Uraian Materi); Ayo Berpikir Kritis; Ayo Tingkatkan Literasimu dengan Membaca; Sekilas Info; E-Info; Rangkuman; Refleksi Diri; Tugas Mandiri; Evaluasi; Yuk, kita Ingat Kembali; Daftar Pustaka; Glosarium; dan Biodata Penulis (Gambar 3).

b. Menyajikan sintaks pembelajaran inkuiri terbimbing yang mengacu pada Llewellyn (2011) antara lain pada bagian Ayo Mengeksplor Fenomena; Ayo Merumuskan Pertanyaan; Ayo Merancang Kegiatan Investigasi; Let's Do It; Ayo Menyusun 
Data Pengamatan; Ayo Menganalisis Data Pengamatan; Ayo Mengonstruk Pengetahuan; Ayo Komunikasikan, dan Mari Menyimpulkan. Hal ini secara tidak langsung mengarahkan penggunaan modul pada pembelajaran dengan model inkuiri terbimbing yang dalam pelaksanaannya melatih siswa berpikir tingkat tinggi dan mengembangkan keterampilan proses sains siswa dalam setiap sintaks pembelajaran inkuiri yang dilakukan.

c. Menggunakan hasil penelitian relevan yang terpublikasi terkait potensi dan kearifan lokal masyarakat Tahura WAR Pesawaran dan gambar-gambar yang diambil dari dokumentasi lapangan di dua lokasi kawasan Tahura WAR yaitu kawasan wisata Air Terjun Tahura WAR dan kawasan kali Cikawat sebagai salah satu bagian dari kawasan pendidikan Tahura WAR.

d. Memfasilitasi penggunaan dalam pembelajaran secara klasikal maupun individual sehingga memudahkan guru maupun siswa.

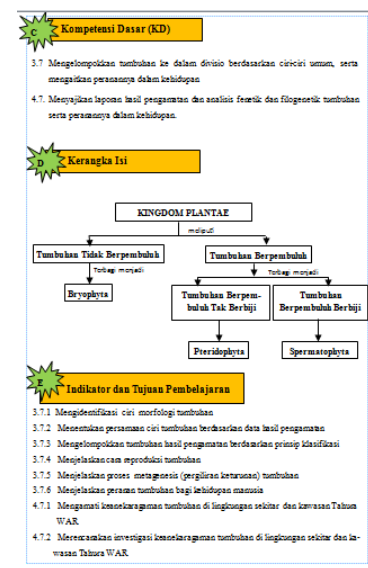

(a)

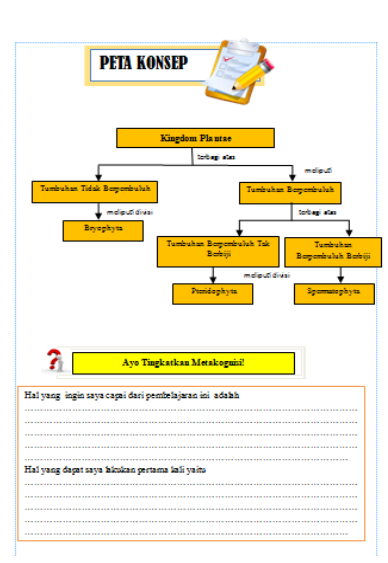

(b)

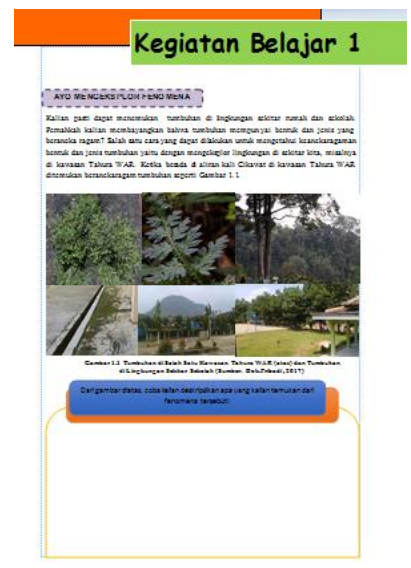

(c)

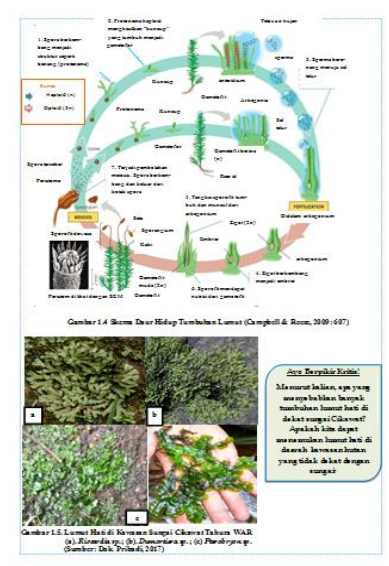

(d)

Gambar 3. Tampilan Sub Bagian Modul Inkuiri Berbasis Potensi dan Kearifan Lokal (a) Kompetensi Inti, Kompetensi Dasar, Kerangka Isi, Indikator dan Tujuan Pembelajaran; (b) peta konsep dan Ayo Tingkatkan Metakognisi; (c) Kegiatan Belajar; (d) Uraian Materi sebagai Pengayaan

\section{Validasi Ahli Media dan Bahan Ajar}

Hasil validasi modul oleh ahli media dan bahan ajar menunjukkan bahwa persentase skor untuk aspek kualitas modul mencakup self-instruction, self-contained, stand alone, adaptive, user friendly, serta penyajian dan kegrafisansecara umum sebesar 93,1\% dengan kategori sangat valid. Aspek self-instruction memperoleh persentase sebesar 94,4\% yang menunjukkan bahwa perumusan kompetensi, tujuan pembelajaran, pengemasan materi yang kontekstual dan spesifik, penyajian alat ukur dan instrumen penilaian siswa, penyediaan informasi dalam modul sudah baik dan layak sehingga tidak perlu direvisi. Aspek selfcontained memperoleh persentase sebesar $87,5 \%$, perolehan tersebut menunjukkan bahwa seluruh materi yang ada dalam modul dapat memberikan pembelajaran secara keseluruhan bagi siswa. Aspek stand-alone memperoleh persentase sebesar 100\%, hal ini menunjukkan bahwa modul yang dikembangkan tidak bergantung pada media atau sumber lain.

Aspek adaptive memperoleh persentase sebesar 87,5\%, nilai tersebut menunjukkan bahwa modul bersifat fleksibel dan menyesuaikan dengan perkembangan ilmu pengetahuan dan teknologi. Aspek user-friendly memperoleh persentase sebesar $100 \%$, perolehan persentase tersebut menunjukkan bahwa modul yang dikembangkan memuat instruksi dan paparan informasi yang mudah dimengerti serta menggunakan bahasa dan istilah umum yang memudahkan siswa dalam merespon dan mengakses modul sesuai keinginan. Sementara itu, aspek penyajian dan kegrafisan memperoleh persentase sebesar $100 \%$ dengan kategori valid yang menunjukkan bahwa modul judul, font, layout, gambar, serta penyajian modul sudah baik, tepat, proporsional, sistematis, dan mudah dipahami. Hasil validasi ahli media dan bahan ajar ditampilkan pada tabel 4.

Tabel 4. Hasil Validasi Modul oleh Ahli Media dan Bahan Ajar

\begin{tabular}{clll}
\hline No. & Aspek yang dinilai & Rerata Skor & Kategori \\
\hline 1. & Self-instruction & $94,4 \%$ & Sangat Valid \\
2. & Self-contained & $87,5 \%$ & Sangat Valid \\
3. & Stand alone & $100 \%$ & Sangat Valid \\
4. & Adaptive & $87,5 \%$ & Sangat Valid \\
5. & User friendly & $100 \%$ & Sangat Valid \\
6. & Penyajian dan Kegrafisan & $100 \%$ & Sangat Valid \\
\hline
\end{tabular}


Secara umum, modul dikatakan valid dan dapat dilanjutkan ke tahap penelitian berikutnya. Adapun saran yang diberikan oleh ahli media dan bahan ajar yaitu terkait penjilidan yang memerlukan teknik agar modul dapat dibuka secara utuh. Hal tersebut perlu diperhatikan sehingga memudahkan siswa dalam menggunakannya. Hasil revisi terkait margin penjilidan modul dapat dilihat pada gambar 4.

\section{Validasi Ahli Materi}

Berdasarkan hasil validasi ahli materi, diketahui bahwa persentase penyajian materi pada modul untuk seluruh aspek yang dinilai yaitu sebesar 89,13\% dengan kategori sangat valid. Adapun saran perbaikan dari validator ahli yaitu: (1) masih perlunya mencermati Kompetensi Dasar (KD) dalam merumuskan indikator pembelajaran, (2) perlu mencermati beberapa konsep materi yang masih salah, (3) mencermati alat evaluasi terkait konsep materi Keanekaragaman Tumbuhan; dan (3) penyajian sub bab materi perlu diperhatikan terutama untuk materi Keanekaragaman Tumbuhan tidak perlu memisahkan divisi Bryophyta, Pteridophyta, dan Spermatophyta menjadi satu kegiatan yang terpisah. Hasil validasi ahli materi ditampilkan pada Tabel 5. Hasil revisi modul berdasarkan saran ahli materi dapat dilihat pada gambar 5, 6, dan 7.

Tabel 5. Hasil Validasi Modul oleh Ahli Materi

\begin{tabular}{clcl}
\hline No. & Aspek yang dinilai & Rerata Skor & Kategori \\
\hline 1. & Kelengkapan Materi & $90 \%$ & Sangat Valid \\
2. & Keakuratan Materi & $90 \%$ & Sangat Valid \\
3. & Kegiatan yang Mendukung Materi & $90 \%$ & Sangat Valid \\
4. & Kemutakhiran Materi & $90 \%$ & Sangat Valid \\
5. & Materi dapat Menunjang Kompetensi Sains Siswa & $95 \%$ & Sangat Valid \\
6. & Materi Mengikuti Sistematika Keilmuan & $90 \%$ & Sangat Valid \\
7. & Materi Mengembangkan Keterampilan dan Kemampuan Berpikir & $90 \%$ & Sangat Valid \\
8. & Materi Merangsang Siswa untuk Mencari Tahu & $90 \%$ & Sangat Valid \\
9. & Potensi Tahura WAR sebagai Sumber Materi Biologi & $90 \%$ & Sangat Valid \\
10. & Nilai-Nilai Kearifan Lokal dalam Materi & $90 \%$ & Sangat Valid \\
11. & Aspek Bahasa & $82,5 \%$ & Sangat Valid \\
\hline
\end{tabular}

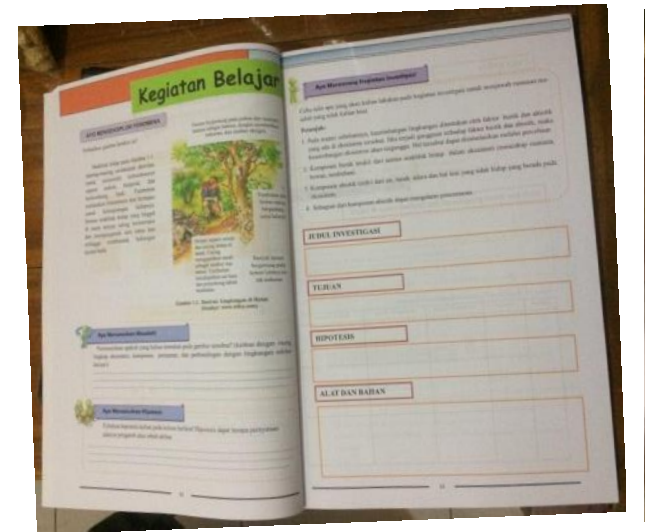

(a)

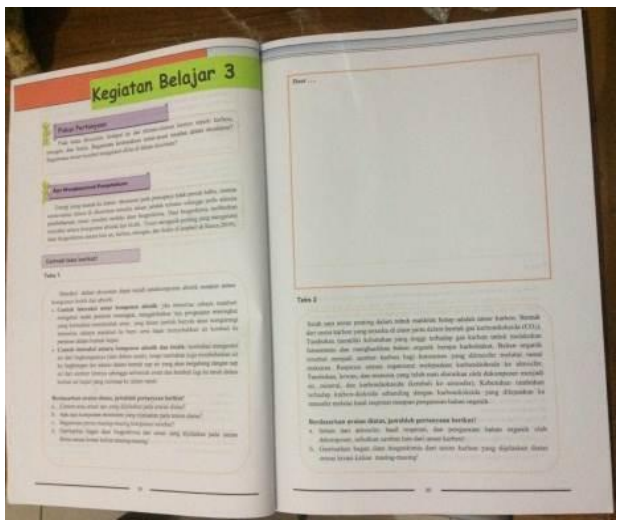

(b)

Gambar 4. Hasil Revisi Margin Penjilidan Modul (a) sebelum revisi (b) sesudah revisi

\section{Validasi Praktisi Lapangan}

Persentase skor hasil validasi praktisi lapangan yaitu sebesar 92,8\% dengan kategori sangat valid. Aspek kegrafisan mendapatkan persentase sebesar $88 \%$, aspek isi materi modul sebesar $88,6 \%$, kebahasaan sebesar $90 \%$, serta aspek penyajian dan manfaat modul mendapatkan persentase $100 \%$. Hal tersebut menunjukkan kategori sangat valid dan tidak perlu direvisi. Komentar yang diberikan oleh praktisi lapangan yakni modul sangat baik, bahasa yang digunakan sangat mudah dimengerti siswa serta ketersediaan modul dapat memudahkan siswa belajar lebih interaktif. Hasil validasi praktisi lapangan ditampilkan pada tabel 6. 
Tabel 6. Hasil Validasi Modul oleh Praktisi Lapangan

\begin{tabular}{clcl}
\hline No. & Aspek yang dinilai & Rerata Skor & Kategori \\
\hline 1. & Kegrafisan & $88 \%$ & Sangat Valid \\
2. & Penyajian & $100 \%$ & Sangat Valid \\
3. & Isi Materi Modul & $88.6 \%$ & Sangat Valid \\
4. & Kebahasaan & $90 \%$ & Sangat Valid \\
5. & Manfaat & $100 \%$ & Sangat Valid \\
\hline
\end{tabular}
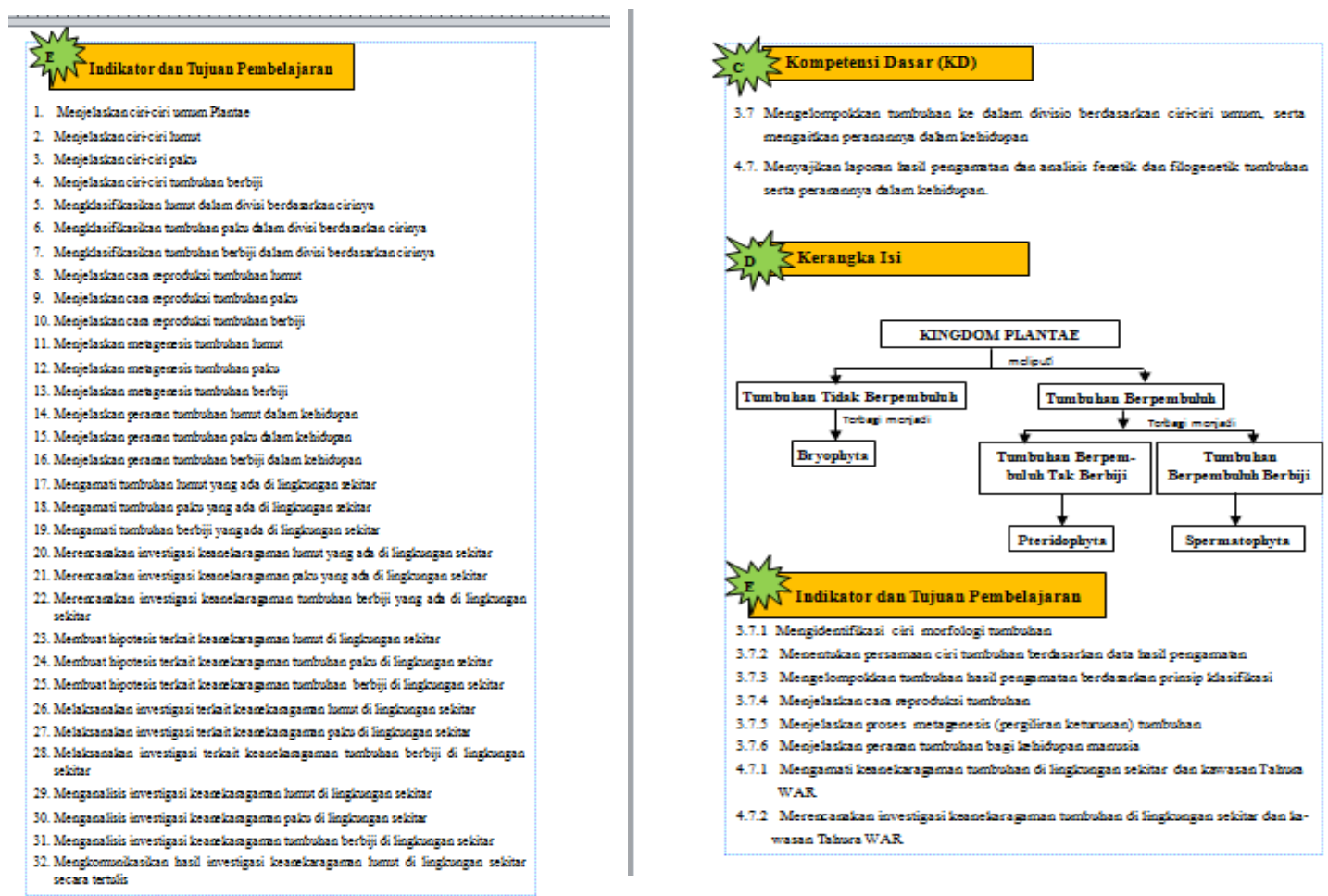

\section{Gambar 5. Hasil Revisi Ahli Materi Terkait Penyederhanaan Indikator}

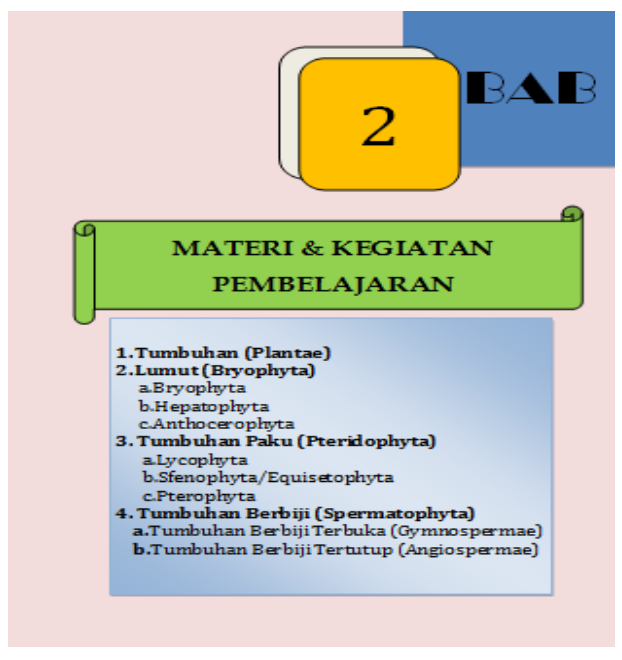

(a)

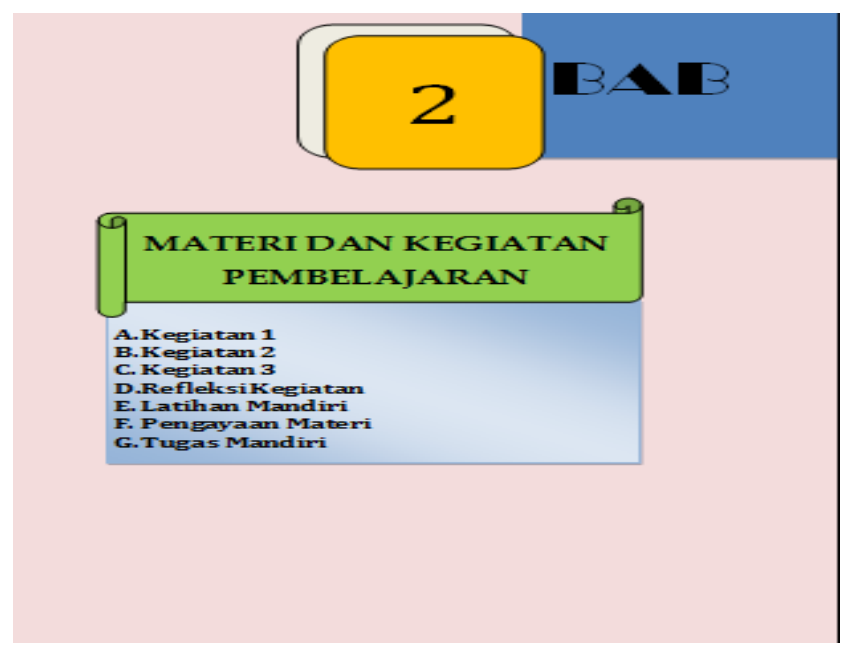

(b)

Gambar 6. Hasil Revisi Ahli Materi Penyajian Sub Materi Keanekaragaman Tumbuhan 


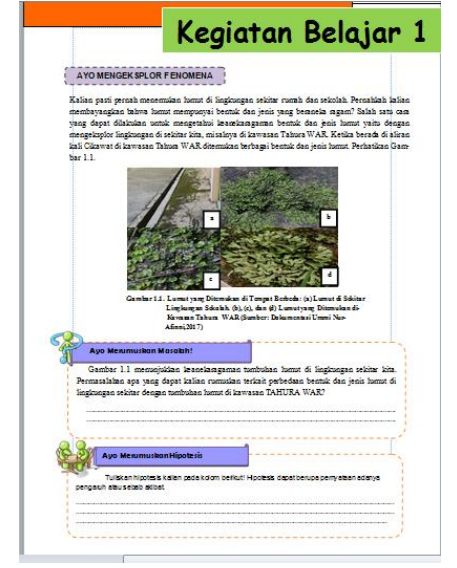

(a)

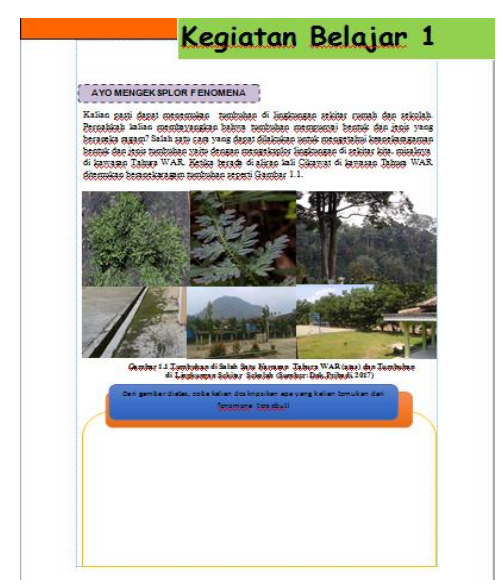

(b)

Gambar 7. Hasil Revisi Ahli Materi Terkait Pemisahan Kegiatan Pembelajaran Berdasarkan Divisi Tumbuhan Bryophyta, Pteridophyta, dan Spermatophyta. a) sebelum revisi; b) sesudah revisi.

\section{Uji Keterbacaan dan Respon Siswa terhadap Modul (Uji Kelompok Kecil)}

Mayoritas siswa memberikan respon positif ( $\geq 70 \%$ ) dengan persentase $83,5 \%$. Hasil tersebut menunjukkan bahwa modul bersifat praktis $(\geq 81 \%)$ dan digunakan lebih lanjut. Hasil respon siswa selengkapnya dapat dilihat pada Gambar8.

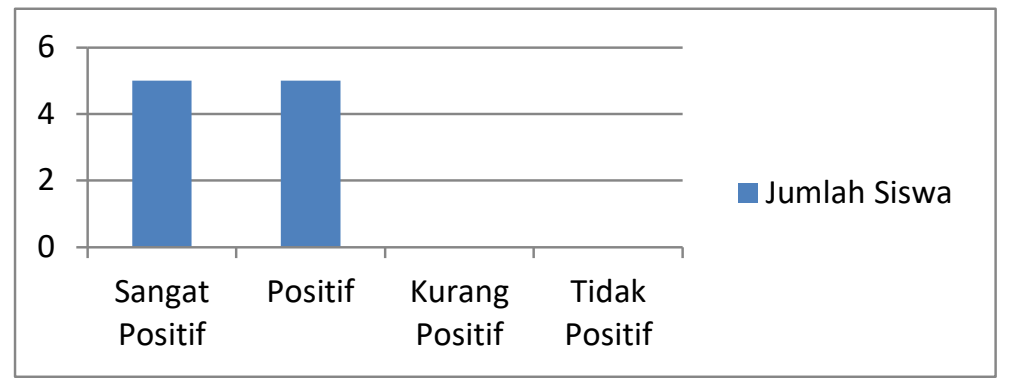

Gambar 8. Respons Siswa terhadap Modul

Hasil uji keterbacaan pada kelompok kecil menunjukkan persentase aspek kemudahan, kemenarikan, manfaat, serta kualitas gambar dan tulisan dalam modul secara berturut-turut yaitu sebesar 82,4\%, 81,5\%, 86,7\%, dan 85\% yang menunjukkan kategori sangat praktis. Hasil uji keterbacaan selengkapnya dapat dilihat pada tabel 8.

Tabel 8. Ringkasan Hasil Uji Keterbacaan

\begin{tabular}{clcl}
\hline No. & Aspek yang dinilai & Rerata Skor & Kategori \\
\hline 1. & Kemudahan & $82,4 \%$ & Sangat praktis \\
2. & Kemenarikan & $81,5 \%$ & Sangat praktis \\
3. & Manfaat & $86,7 \%$ & Sangat praktis \\
4. & Kualitas gambar dan tulisan & $85 \%$ & Sangat praktis \\
\hline
\end{tabular}

Menurut siswa, modul menarik baik dari segi gambar, tulisan, maupun kesesuaian dengan materi yang dipelajari. Beberapa siswa menyatakan bahasa yang digunakan dalam modul mudah dipahami sehingga lebih mudah dan senang dalam mempelajarinya serta membantu siswa dalam mempelajari materi biologi. Walaupun demikian, terdapat beberapa saran yang diberikan siswa mengenai modul yang dikembangkan, yakni (a) warna pada cover seharusnya lebih terang; (b) perlu penambahan gambar pada cover yang berkaitan dengan materi dalam isi modul (pada modul Ekosistem dan Perubahan Lingkungan); dan (c) penjabaran dan penjelasan terkait latihan soal lebih diperjelas. 


\section{PEMBAHASAN}

Bahan ajar yang dipilih dalam penelitian pengembangan ini adalah modul inkuiri terbimbing berbasis potensi dan kearifan lokal untuk mata pelajaran biologi pada materi Keanekaragaman Tumbuhan, Ekosistem, dan Perubahan Lingkungan di SMA Negeri 1 Padang Cermin. Menurut Robinson \& Crittenden (1972) dan Departemen Pendidikan Nasional (2008), modul merupakan bahan ajar berupa sekumpulan materi dan unit aktivitas pembelajaran yang dirancang untuk topik tertentu serta dilengkapi dengan ketentuan penilaian dan evaluasi agar siswa mampu mencapai tujuan pembelajaran. Pembuatan modul memiliki tujuan antara lain untuk mengefisienkan waktu pembelajaran, mengurangi pembicaraan verbal dan teknik instruksi dari guru, memberi peluang bagi siswa untuk belajar diluar kelas secara mandiri, meningkatkan evaluasi sehingga kualitas pembelajaran meningkat, serta memaksimalkan penggunaan media dan latihan kelompok (Mulyasa, 2006; Robinson, \& Crittenden, 1972).

Modul dalam penelitian ini dikembangkan dengan menggunakan model penelitian dan pengembangan ADDIE dan disusun berdasarkan sintaks model pembelajaran inkuiri terbimbing (Kemendikbud, 2013). Materi modul dikembangkan berdasarkan hasil observasi lapangan dan hasil-hasil penelitian relevan yang terpublikasi serta referensi pembelajaran yang berkaitan dengan potensi dan kearifan lokal kawasan Taman Hutan Raya Wan Abdul Rachman (Tahura WAR). Alasan penentuan Tahura WAR sebagai sumber materi modul, antara lain (1) belum pernah digunakan guru sebagai sumber belajar pembelajaran biologi di SMAN 1 Padang Cermin; (2) merupakan potensi lokal yang khas karena tidak semua daerah di Indonesia (hanya 22 provinsi) memiliki Taman Hutan Raya (Ditjen PHKA, 2008); (3) memiliki potensi flora, fauna dan kearifan lokal (repong) yang merupakan kajian materi biologi; serta 4) bersifat fleksibel karena dapat diintegrasikan untuk lebih dari satu materi.

Modul yang dikembangkan memiliki bagian pembukaan, inti, dan penutup. Bagian pembukaan mencakup cover, kata pengantar, daftar isi, daftar gambar, dan daftar tabel. Bagian inti terdiri atas tiga bab yaitu pendahuluan, materi, dan evaluasi. Bab pertama yaitu pendahuluan mencakup deskripsi singkat modul, Kompetensi Inti (KI), Kompetensi Dasar (KD), kerangka isi, indikator, dan tujuan pembelajaran. Bab kedua mencakup kegiatan pembelajaran, refleksi kegiatan, latihan mandiri, pengayaan materi, dan tugas mandiri. Sedangkan bab ketiga mencakup evaluasi tes Keterampilan Proses Sains (KPS), tes keterampilan berpikir kritis, dan metakognisi serta petunjuk penilaian evaluasi. Bagian penutup terdiri atas daftar rujukan, glosarium, kunci jawaban evaluasi, dan daftar riwayat hidup penulis.

Kegiatan Belajar yang ada dalam modul mencakup tiga kegiatan belajar yang disesuaikan dengan tiga topik yang diambil yaitu Keanekaragaman Tumbuhan, Ekosistem, dan Perubahan Lingkungan. Kegiatan Belajar pada materi Keanekaragaman Tumbuhan mencakup kegiatan investigasi di lingkungan sekolah, kegiatan investigasi di Tahura WAR, dan kegiatan membandingkan karakteristik tumbuhan lumut, tumbuhan paku, dan tumbuhan berbiji berdasarkan hasil investigasi di lingkungan sekitar dan Tahura WAR. Kegiatan Belajar pada materi Ekosistem mencakup kegiatan investigasi komponen penyusun ekosistem yang kemudian menjadi dasar kegiatan selanjutnya yaitu terkait rantai makanan dalam ekosistem. Kegiatan III dalam modul Ekosistem berupa kegiatan mencermati teks berkaitan dengan daur biogeokimia. Terdapat pertanyaan pada setiap teks yang disajikan serta instruksi bagi siswa untuk menggambarkan daur biogeokimia yang terdapat dalam teks sebagai hasil dari analisis teks yang diberikan.

Sementara itu, Kegiatan Belajar yang terdapat pada materi Perubahan Lingkungan meliputi kegiatan mengumpulkan informasi atau artikel terkait perubahan lingkungan yang ada di Kabupaten Pesawaran dan Provinsi Lampung untuk dianalisis faktor penyebab perubahan lingkungan dan penentuan perubahan lingkungan yang terjadi mengarah pada kerusakan lingkungan atau tidak. Kegiatan selanjutnya yaitu kegiatan investigasi pencemaran lingkungan serta investigasi permasalahan limbah di lingkungan sekitar. Terdapat refleksi diri dan evaluasi mandiri di setiap akhir kegiatan untuk mengukur pemahaman dan penguasaan siswa untuk dapat melanjutkan ke kegiatan selanjutnya. Kegiatan investigasi dalam Kegiatan Belajar setiap modul mengacu pada sintaks model pembelajaran inkuiri terbimbing (Llewellyn, 2013) yaitu mengeksplor fenomena, memfokuskan pertanyaan, merancang kegiatan investigasi, menyusun data investigasi, menganalisis data pengamatan, mengonstruk pengetahuan dan mengomunikasikan.

Modul biologi yang dikembangkan telah melewati tahap validasi ahli dan tahap uji coba kelompok kecil. Kriteria penilaian diadaptasi dari Akbar (2015) untuk menentukan tingkat validitas dan kepraktisan produk. Hasil validasi oleh ahli media dan bahan ajar, ahli materi, dan praktisi lapangan. Hasil validasi ahli media dan bahan ajar sebesar 93,1\%; hasil validasi dari ahli materi sebesar 89,13\%; dan dari praktisi lapangan sebesar 92,8\%. Validasi yang dilakukan oleh ahli media dan bahan ajar, ahli materi, dan praktisi lapangan menunjukkan bahwa modul yang dikembangkan tergolong valid dan telah dikembangkan sesuai lima karakteristik utama modul, yaitu self-instruction, self-contained, stand-alone, adaptive, dan user friendly (Ali, Ghazi, Khan, Hussain, \& Faitma, 2010; Departemen Pendidikan Nasional, 2008; Robinson, \& Crittenden, 1972). Hasil uji coba oleh 10 orang siswa SMAN 1 Padang Cermin meunjukkan lima orang siswa memberikan respon sangat positif dan lima orang siswa memberikan respon positif. Hal ini menunjukkan bahwa modul yang dikembangkan bersifat praktis untuk digunakan dalam proses pembelajaran. 
Pengembangan modul inkuiri terbimbing berbasis potensi dan kearifan lokal cukup banyak dilakukan. Walaupun demikian, pengembangan tersebut terbatas pada pengintegrasian potensi dan kearifan lokal untuk satu materi saja seperti modul inkuiri terbimbing yang dikembangkan Novana, Sajidan, \& Maridi (2014) terbatas pada materi tumbuhan lumut dan paku; Mumpuni (2013) dan Anwari (2015) yang terbatas pada keanekaragaman hayati; serta Dewi, Karno, \& Purnama (2017) \& Prabowo (2016) yang terbatas pada materi ekosistem. Hal ini berbeda dengan modul inkuiri terbimbing berbasis potensi dan kearifan lokal Tahura WAR yang dapat mencakup lebih dari satu materi yaitu keanekaragaman tumbuhan, ekosistem, dan perubahan lingkungan. Dengan demikian, guru akan lebih efisien dalam memanfaatkan sumber belajar kontekstual Tahura WAR karena memiliki cakupan materi yang lebih luas.

Nilai lebih dari modul yang dikembangkan yaitu menyajikan evaluasi pembelajaran untuk mengukur penguasaan keterampilan berpikir kritis, metakognisi, dan keterampilan proses sains siswa yang terdapat pada bab ketiga modul. Hal ini merupakan hal baru yang belum ada pada modul yang dikembangkan peneliti lain yang hanya mengukur pemahaman konsep terhadap materi dalam modul (Anwari, 2015; Mumpuni, 2014; Novana, Sajidan, Maridi, 2014; Prabowo, 2016) untuk meningkatkan hasil belajar siswa (Farhana, 2015). Adanya alat evaluasi penguasaan keterampilan tersebut memberikan pengalaman dan melatih siswa untuk mengembangkan keterampilan abad 21 siswa karena alat evaluasi yang digunakan bukan sekedar tes yang hanya menuntut siswa mengingat pengetahuan, soal pilihan ganda sederhana, maupun tes yang menuntut jawaban singkat (Doganay \& Bal, 2010).

Modul inkuiri terbimbing berbasis potensi dan kearifan lokal Tahura WAR dapat digunakan sebagai penunjang pembelajaran interaktif sehingga siswa mendapatkan pengalaman belajar yang berkaitan dengan lingkungan sekitarnya dan melatih keterampilan proses sains siswa. Modul dapat digunakan baik dalam pembelajaran di kelas maupun pembelajaran di rumah sehingga dapat mengembangkan keterampilan berpikir kritis dan metakognisi siswa. Selain itu, pengenalan potensi daerah sekitar juga dapat mendorong tumbuhnya jiwa kewirausahaan siswa (Ibrohim, 2015). Hal ini sesuai dengan penelitian Anafiyah, Sulistiyowati, \& Susilawati (2015) terkait relevansi antara materi kewirausahaan dan pengintegrasiannya dalam modul materi ekosistem dan pencemaran lingkungan. Berdasarkan hasil tersebut, modul inkuiri terbimbing berbasis potensi lokal Tahura WAR dapat disempurnakan lagi melalui penyisipan materi kewirausahaan, misalnya dengan menyisipkan materi atau informasi terkait penjualan produk daur ulang sampah dan limbah, informasi tentang keuntungan dalam membudidayakan tanaman dalam kebun repong yang dilakukan oleh masyarakat sekitar Tahura WAR maupun budidaya tumbuhan lainnya yang dapat mendatangkan penghasilan tambahan.

\section{SIMPULAN}

Modul inkuiri berbasis potensi dan kearifan lokal dikembangkan berdasarkan model pengembangan ADDIE. Potensi dan kearifan lokal yang diintegrasikan dalam modul yaitu potensi dan kearifan lokal masyarakat Taman Hutan Raya Wan Abdul Rachman di Kabupaten Pesawaran, Lampung. Hasil validasi menunjukkan modul yang dikembangkan memiliki kategori sangat valid dan hasil uji keterbacaan menyatakan bahwa modul praktis digunakan dan mendapatkan respon positif dari siswa. Saran yang perlu diperhatikan, antara lain (1) perlunya melakukan sosialisasi terkait modul yang dikembangkan baik dalam forum ilmiah maupun forum guru (MGMP); (2) perlunya menguasai model pembelajaran inkuiri terbimbing agar kegiatan pembelajaran dalam modul dapat terlaksana dengan baik; (3) perlunya dilakukan penelitian lebih lanjut melalui penerapan modul dalam proses pembelajaran untuk mengetahui pengaruhnya terhadap pengembangan keterampilan abad 21 siswa.

\section{DAFTAR RUJUKAN}

Aditomo, A., \& Klieme, E. (2020). Forms of Inquiry-Based Science Instruction and Their Relations with Learning Outcomes: Evidence from High and Low-Performing Education Systems. International Journal of Science Education, 42(4), 504525. https://doi.org/10.1080/09500693.2020.1716093

Akbar, S. (2015). Instrumen Perangkat Pembelajaran. PT Remaja Rosdakarya.

Ali, R., Ghazi, S. R., Khan, M. S., Hussain, S., \& Faitma, Z. T. (2010). Effectiveness of Modular Teaching in Biology at Secondary Level. Asian Social Science, 6(9), 49-54.

Anafiyah, K., Sulistiyowati, E., \& Susilawati, L. (2015). Pengembangan Modul Ekosistem Berorientasi Kewirausahaan untuk SMA/MA. Kaunia, 11(1), 72-77.

Anwari. (2015). Pengembangan Modul Pembelajaran Biologi Berbasis Kearifan Lokal di Taman Nasional Gunung Merapi untuk SMA/MA Kelas X Materi Keanekaragaman Hayati. UIN Sunan Kalijaga.

Ausubel, D.P.; Novak, J.D.; Hanesian, H. (1978). Educational Psychology: A Cognitive View (2nd Editio). Holt, Rinehart \& Winston.

Basari, A. (2014). Penguatan Kurikulum Muatan Lokal dalam Pembelajaran di Sekolah Dasar. Seminar Nasional 2014.

Bevins, S., \& Price, G. (2016). Reconceptualising inquiry in science education. International Journal of Science Education, 38(1), 17-29. https://doi.org/10.1080/09500693.2015.1124300

Binkley, M. (2012). Assessment and Teaching of $21^{\text {st }}$ Century Skills (P. Griffin (ed.)). Springer Science \& Business Media B.V. 
Bunterm, T., Lee, K., Ng Lan Kong, J., Srikoon, S., Vangpoomyai, P., Rattanavongsa, J., \& Rachahoon, G. (2014). Do Different Levels of Inquiry Lead to Different Learning Outcomes? A comparison between guided and structured inquiry. International Journal of Science Education, 36(12), 1937-1959. https://doi.org/10.1080/09500693.2014.886347

Colburn. (2000). An Inquiry Primer. Science Scope.

Crawford, B. A. (2007). Learning to teach science as inquiry in the rough and tumble of practice. Journal of Research in Science Teaching, 44(4), 613-642. https://doi.org/10.1002/tea.20157

De Gale, S., \& Boisselle, L. N. (2015). The Effect of POGIL on Academic Performance and Academic Confidence. Science Education International, 26(1), 56-79.

Departemen Pendidikan Nasional. (2008). Teknik Penyusunan Modul. Direktorat Pembinaan Sekolah Menengah dan Kejuruan.

Desuciani, A. (2012). Etnobotani pangan dan Obat Masyarakat Sekitar Kawasan Taman Hutan Raya Wan Abdul Rachman (Studi Kasus pada Suku Lampung Pesisir). Institut Pertanian Bogor.

Dewi, R.; Karno, R.; \& Purnama, A. A. (2017). Pengembangan Modul Biologi Berbasis Inkuiri Terbimbing pada Materi Pokok Ekosistem Kelas X SMA Negeri 1 Tambusai. Jurnal Mahasiswa FKIP Universitas Pasir Pengaraian, 3(1), 00-00.

Ditjen PHKA. (2008). Kebijakan Pembangunan Taman Hutan Raya.

Doganay, A. \& Bal, A. P. (2010). The Measurement of Students’ Achievement in Teaching Primary School Fifth Year Mathematcs Classes. Educational Science: Theory \& Practice, 10(1), 199-215.

Fakayode, S. O., Mayes, J. P., Kanipes, M. I., Johnson, D., \& Cuthbertson, E. L. (2017). Promoting Student Learning in Criminal Justice, STEM, and Forensic Science: Aggie Sleuth Initiative (AggieSI)-Guided Inquiry Learning Experience. Journal of Criminal Justice Education, 28(2), 192-206. https://doi.org/10.1080/10511253.2016.1199720

Fang, S. C., Hsu, Y. S., Chang, H. Y., Chang, W. H., Wu, H. K., \& Chen, C. M. (2016). Investigating the effects of structured and guided inquiry on students' development of conceptual knowledge and inquiry abilities: a case study in Taiwan. International Journal of Science Education, 38(12), 1945-1971. https://doi.org/10.1080/09500693.2016.1220688

Farhana, Z. (2015). Pengembangan Modul Biologi Berbasis Inkuir Terbimbing untuk Meningkatkan Hasil Belajar Siswa pada Materi Pokok Ekosistem Kelas X di MA Al-Mukarrom Ponorogo.

Greenstein, L. (2012). Assessing 21st Centruy Skills: A Guide to Evaluating Mastery and Authentic Learning. Corwin A Sage Company.

Hein, S. M. (2012). Positive impacts using POGIL in organic chemistry. Journal of Chemical Education, 89(7), 860-864. https://doi.org/10.1021/ed100217v

Ibrohim. (2015). Pengembangan Pembelajaran IPA/Biologi Berbasis Discovery/Inquiry dan Potensi Lokal untuk Meningkatkan Keterampilan dan Sikap Ilmiah serta Menumbuhkan Jiwa Kewirausahaan. Sains \& Enterpreneurship, O(0), 1-19.

Koksal, E. A., \& Berberoglu, G. (2014). The Effect of Guided-Inquiry Instruction on 6th Grade Turkish Students' Achievement, Science Process Skills, and Attitudes Toward Science. International Journal of Science Education, 36(1), 66-78. https://doi.org/10.1080/09500693.2012.721942

Kristiani, N. (2016). Dinamika Perkembangan Kurikulum 2013.

Labouta, H. I., Kenny, N. A., Li, R., Anikovskiy, M., Reid, L., \& Cramb, D. T. (2018). Learning Science by Doing Science: An Authentic Science Process-Learning Model in Postsecondary Education. International Journal of Science Education, 40(12), 1476-1492. https://doi.org/10.1080/09500693.2018.1484966

Llewellyn, D. (2013). Teaching High School Science Through Inquiry and Argumentation. Corwin.

Marliana \& Hikmah, N. (2013). Pendidikan Berbasis Muatan Lokal sebagai Sub Komponen Kurikulum. Dinamika Ilmu, 13(1), $105-119$.

Minner, D. D., Levy, A. J., \& Century, J. (2010). Inquiry-Based Science Instruction-What is it and does it Matter? Results from a Research Synthesis Years 1984 to 2002. Journal of Research in Science Teaching, 47(4), 474-496. https://doi.org/10.1002/tea.20347

Mullins, M. H. (2017). Actively Teaching Research Methods with a Process Oriented Guided Inquiry Learning Approach. Journal of Teaching in Social Work, 37(4), 309-321. https://doi.org/10.1080/08841233.2017.1347122

Mulyasa, E. (2006). Kurikulum yang Disempurnakan. PT Remaja Rosdakarya.

Mumpuni, K. (2013). Potensi Pendidikan Keunggulan Lokal Berbasis Karakter Dalam Pembelajaran Biologi Di Indonesia. Prosiding Seminar Biologi, 2002, 1-7.

Mumpuni, K. E. (2014). Integrasi Potensi dan Kearifan Lokal Pegunungan Muria sebagai Pengembangan Modul Materi Keanekaragaman Hayati dan Konservasi untuk Siswa SMA. Universitas Negeri Malang.

Mundy, C., \& Potgieter, M. (2019). Refining Process-oriented Guided Inquiry Learning for Chemistry Students in an Academic Development Programme. African Journal of Research in Mathematics, Science and Technology Education, 23(2), 145156. https://doi.org/10.1080/18117295.2019.1622223

Novana, T., Sajidan., \& Maridi. (2014). Pengembangan Modul Inkuiri Terbimbing Berbasis Potensi Lokal pada Materi Tumbuhan Lumut (Bryophyta) dan Tumbuhan Paku (Pteridophyta). Inkuiri: Jurnal Pendidikan IPA, 3(2), $108-122$. 
Peraturan Menteri Pendidikan dan Kebudayaan Nomor 24 Tahun 2016. (n.d.). Kompetensi Inti dan Kompetensi Dasar. Peraturan Pemerintah Republik Indonesia Nomor 108 tahun 2015. (2015). Peraturan Pemerintah tentang Perubahan Atas Peraturan Pemerintah Nomor 28 Tahun 2011 Tentang Pengelolaan Kawasan Suaka Alam dan Kawasan Pelestarian Alam. Lembaran Negara Republik Indonesia.

Prabowo, D. L. (2016). Pengembangan Modul Berbasis Potensi Lokal pada Materi Ekosistem sebagai Bahan Ajar di SMAN 1 Tanjungsari Gunungkidul. Proceeding Biology Education Conference, 13(1), 192-195.

Prastowo, A. (2015). Panduan Kreatif Membuat Bahan Ajar Inovatif. Diva Press.

Robinson, J.W. \& Crittenden, W. B. (1972). Learning Modules: A Concept for Extension Educators? University of Ilinois \& Houston Baptist College.

Song, Y. (2016). "We found the 'Black Spots' On Campus On Our Own”: Development of Inquiry Skills in Primary Science Learning with BYOD (Bring Your Own Device). Interactive Learning Environments, 24(2), 291-305. https://doi.org/10.1080/10494820.2015.1113707

Stender, A., Schwichow, M., Zimmerman, C., \& Härtig, H. (2018). Making Inquiry-Based Science Learning Visible: The Influence of CVS and Cognitive Skills on Content Knowledge Learning in Guided Inquiry. International Journal of Science Education, 40(15), 1812-1831. https://doi.org/10.1080/09500693.2018.1504346

Tytler, R. (2007). Re-imagining Science Education: Engaging Students in Science fro Australia's Future. Camberville VIC

Undang-undang Republik Indonesia Nomor 30 Tahun 2003. (n.d.). Sistem Pendidikan Nasional. Lembaran Negara Republik Indonesia.

UPTD Tahura WAR. (2008). Buku Informasi Pembangunan Taman Hutan Raya Wan Abdul Rachman. UPTD Tahura WAR Dinas Kehutanan Provinsi Lampung. 